\title{
PEMANFAATAN BOKASHI KOTORAN TERNAK AYAM TERHADAP PRODUKTIFITAS TANAMAN CAISIN
}

\author{
Amalan Tomia \\ Staf Pengajar Faperta UMMU-Ternate, $\boldsymbol{e}$-mail: -
}

\begin{abstract}
ABSTRAK
Bokashi adalah suatu kata dalam bahasa Jepang yang berarti bahan organik yang difermentasikan. Bokashi dibuat dengan memfermentasikan bahan-bahan organik dengan menggunakan teknologi EM-4 serta dapat digunakan sebagai pupuk organik untuk menyuburkan tanah, meningkatkan pertumbuhan dan produksi tanaman. Bokashi dapat dibuat dalam beberapa hari dan langsung dapat digunakan. Penelitian ini bertujuan untuk meningkatkan pengetahuan petani dalam pemanfaatan bokashi kotoran ternak ayam pada tanaman caisin. Penelitian ini dilaksanakan menggunakan Rancangan Acak Lengkap (RAL) dengan empat perlakuan dan lima ulangan. Perlakuan yang diterapkan adalah : (TO) tanpa pemberian bokashi, (T1) campuran tanah dan bokashi 1:0,5 (T2) campuran tanah dan bokashi $1: 1$ dan (T3) campuran tanah dan bokashi 1 : 1,5. Analisis data menggunakan Analisis of Variance (ANOVA) satu arah (one way) yang aplikasinya menggunakan program SPSS 10.0 dan apabila terdapat perbedaan dilanjutkan dengan analisis Uji Duncan. Berdasarkan ANOVA diperoleh hasil bahwa pemberian bokashi berpengaruh sangat nyata terhadap tinggi dan berat segar tanaman caisin $(P<0,01)$. Hasil Uji Duncan menunjukkan bahwa untuk tinggi tanaman caisin pada $T_{1}: 36,28 \mathrm{~cm}$ berbeda nyata $(P<0,05)$ dan lebih tinggi dibandingkan dengan $T_{0}: 34,28 \mathrm{~cm}, T_{2}: 32,58 \mathrm{~cm}$ dan $T_{3}: 28,84 \mathrm{~cm} . T_{0}$ tidak berbeda nyata dengan $T_{2}$ tetapi berbeda nyata dengan $T_{1}$ dan $T_{3}(P<0,05)$. Tinggi tanaman caisin yang paling rendah adalah pada $T_{3}$. Berat segar tanaman caisin pada $T_{1}: 161,60 \mathrm{gr}$ tidak berbeda nyata $(P>0,05)$ dengan $T_{2}: 156,88 \mathrm{gr}$ dan lebih tinggi dibandingkan dengan $T_{0}: 126,84 \mathrm{gr}$ dan $T_{3}$. : 133,96 gr. Berat segar tanamam caisin yang paling ringan adalah pada perlakuan $T_{0}$.
\end{abstract}

Kata Kunci: Bokashi, kotoran ternak ayam dan tanaman caisin

\section{PENDAhuluan}

\subsection{Latar Belakang}

Proses pelaksanaan pembangunan pertanian tidak luput dari peran serta masyarakat sebagai subyek dan pemerintah sebagai penentu kebijaksanaan pembangunan. Kerjasama yang baik antar pemerintah dan masyarakat dalam membangun pertanian merupakan kunci utama keberhasilan pembangunan pertanian untuk menciptakan kesejahteraan masyarakat.

Sektor pertanian sebagai salah satu sektor penunjang keberhasilan pembangunan nasional diharapkan mampu memberikan kontribusi yang cukup besar. Hal tersebut menjadi sebuah tantangan bagi para pelaku dibidang pertanian untuk meningkatkan kemampuan maupun produktivitasnya. Sebagai salah satu bagian dari pertanian maka sub sektor peternakan selalu berusaha untuk dapat berpartisipasi aktif dalam pembangunan nasional, yang diantaranya adalah mengadakan penelitian-penelitian untuk menciptakan teknologi-teknologi baru dibidang peternakan serta berupaya meningkatkan kemampuan peternak dalam melaksanakan usaha taninya. Usaha peternakan tidak hanya menghasilkan produk-produk pokok (daging, telur dan susu) tetapi juga menghasilkan produk sampingan seperti kulit, tulang, darah dan kotoran.

Marsono (2003), menyatakan bahwa kandungan hara pada pupuk kandang yang dihasilkan ternak ternak ayam adalah $\mathrm{N} 0,75 \%$, $\mathrm{P} 0,50 \%, \mathrm{~K} 0,45 \%$ dan kandungan air $60 \%$. Dengan kandungan $\mathrm{N}$ yang relatif tinggi, kotoran ternak ayam sangat baik untuk dimanfaatkan sebagai pupuk. Ternak ayam dewasa dapat 
menghasilkan faeces rata-rata 40 - 60 kg/ekor/bulan (Balitnak, 2005).

Bokashi adalah suatu kata dalam bahasa Jepang yang berarti bahan organik yang difermentasikan. Bokashi dibuat dengan memfermentasikan bahan-bahan organik dengan menggunakan teknologi $\mathrm{EM}_{-4}$ serta dapat digunakan sebagai pupuk organik untuk menyuburkan tanah, meningkatkan pertumbuhan dan produksi tanaman. Bokashi dapat dibuat dalam beberapa hari dan langsung dapat digunakan (Subadiyasa, 1997).

Sutanto (2005), menyatakan bahwa Effective Microorganisme (EM-4) merupakan kultur campuran berbagai jenis mikrobia yang bermanfaat yang berasal dari lingkungan tanah dan dapat dimanfaatkan sebagai inokulan untuk meningkatkan keanekaragaman mikrobia tanah sehingga dapat memperbaiki kesehatan tanah, kualitas tanah, lingkungan fisik, kimia, dan biologi tanah, menekan pertumbuhan hama dan penyakit tanah. Selain itu juga dapat meningkatkan kapasitas fotosintesis tanaman, meningkatkan kapasitas bahan organik sebagai sumber pupuk sehingga dapat memperbaiki tumbuhan dan hasil tanaman.

Menurut Indriyani (2006), peranan bakteri dalam EM-4 adalah sebagai berikut : 1). Bakteri fotosintetik : dapat mensintesis senyawa nitrogen dan hasilnya dapat diserap secara langsung oleh tanaman; 2). Bakteri Asam Laktat, Lactobacillus $s p .:$ merupakan bahan sterilisasi yang kuat yang dapat menekan mikroorganisme berbahaya dan dapat menguraikan bahan organik dengan cepat; 3). Streptomyces $s p .:$ mengeluarkan enzim yang bersifat racun terhadap hama dan penyakit yang merugikan; 4) ragi (yeast) : menghasilkan bakteri yang berguna untuk pertumbuhan sel dan pembelahan akar; 5). Actinomycetes sp.: bertugas untuk mengendalikan bakteri patogen, menekan jamur dan bakteri. Selain itu juga dapat menciptakan kondisi yang baik untuk perkembangan mikroorganisme

Setiyati (2000), menyatakan bahwa syarat tumbuh tanaman caisin adalah tanah yang subur gembur dan banyak mengandung bahan organik serta tidak becek. dapat tumbuh dengan produksi baik pada suhu antara $27-25^{\circ} \mathrm{C}, \mathrm{pH} 5,9-8,2$ dan penggunaan pupuk organik pada polybag dengan ukuran diameter $15 \mathrm{~cm}$, perbandingan antara tanah dan pupuk kandang yang diberikan adalah 1 : 1 (Rukmana 1994). Pada penelitian ini digunakan perbandingan media tanam antara bokashi dan tanah masing-masing antar perlakuan adalah sebagai berikut : perlakuan pertama (T0) : tanah tanpa bokashi, kedua (T1) : campuran tanah dan bokashi $1: 0,5$, ketiga (T2) : campuran tanah dan bokashi $1: 1$ dan keempat T3 : campuran tanah dan bokashi $1: 1,5$.

Pemanfaatkan kotoran ternak sebagai bahan pupuk kandang untuk lahan pertaniannya, jarang dilakukan. Selain itu juga didapat faeces sebagai hasil sampingannya, ternak juga menghasilkan faeces rata-rata 40-60 $\mathrm{kg} / \mathrm{ekor} / \mathrm{bulan}$. Selama ini kotoran yang ada dikelompok tani tersebut hanya ditumpuk di belakang kandang sampai menjadi pupuk jadi dengan waktu yang relatif lama. Supaya kotoran ternak tersebut dapat dimanfaatkan bagi kepentingan petani dengan waktu yang lebih singkat serta tidak menjadikan masalah bagi lingkungan sekitar, baik karena bau ataupun penyakit yang akan ditimbulkan, maka diperlukan suatu teknologi bokashi.

Biasanya petani disamping beternak ternak ayam, mereka pada umumnya juga bertani, khususnya sayur-sayuran. Dengan demikian bokashi yang dihasilkan dapat dimanfaatkan untuk tanaman tersebut. Berdasarkan uraian di atas, maka perlu dilakukan penelitian tentang " Aplikasi Pemanfaatan Bokashi Kotoran Ternak ayam Pada Tanaman Caisin”.

\subsection{Tujuan Penelitian}

Adapun tujuan yang ingin dicapai dalam pelaksanaan kajian ini adalah sebagai berikut; Mengetahui pengaruh pemberian bokashi kotoran ternak ayam pada tinggi dan berat segar tanaman caisin.

\subsection{Hipotesis}

Pemberian bokashi kotoran ternak ayam dapat mempengaruhi tinggi dan berat segar tanaman caisin.

\section{METODE PENELITAIN \\ 2.1. Tempat dan Waktu Penelitain}

Penelitian ini dilakukan di Kelurahan Tobona, Kecamatan Ternate Selatan, Kota Ternate, pada bulan Januari 2012

\subsection{Alat dan Bahan}

Alat yang digunakan adalah . cangkul, ember, gembor kapasitas 10 liter, karung plastik kapasitas $50 \mathrm{~kg}$, thermometer ruangan, Seratus (100) kantong polybag dengan ukuran diameter $15 \mathrm{~cm}$, pengaris ukuran $50 \mathrm{~cm}$, timbangan kapasitas 2,5 kg dengan tingkat akurasi $0.01 \mathrm{~kg}$, dan timbangan kapasitas $5 \mathrm{~kg}$ dengan tingkat akurasi $0.01 \mathrm{~kg}$. 
Bahan yang dipakai untuk penelitian ini adalah kotoran ternak ayam sebanyak $30 \mathrm{~kg}, \mathrm{EM}_{-4} 2$ sendok makan, tetes 1 sendok makan, bekatul 1 $\mathrm{kg}$ dan benih tanaman caisin.

\subsection{Metode Penelitian}

\subsubsection{Metode pengumpulan data}

Pengumpulan data dalam kajian ini adalah dengan melakukan pengamatan langsung terhadap tinggi dan berat segar tanaman caisin yang terdiri dari empat perlakuan dan lima ulangan. Pengamatan tanaman caisin dilakukan seminggu sekali selama satu bulan, adapun perlakuannya adalah sebagai berikut : $\mathrm{T}_{0}, \mathrm{~T}_{1}, \mathrm{~T}_{2}$ dan $\mathrm{T}_{3}$

$\mathrm{T}_{0}$ : tanah tanpa bokashi

$\mathrm{T}_{1} \quad$ : campuran tanah dan bokashi $=1: 0,5$

$\mathrm{T}_{2} \quad$ : campuran tanah dan bokashi $=1: 1$

$\mathrm{T}_{3}:$ campuran tanah dan bokashi $=1: 1,5$

\subsubsection{Prosedur Penelitian}

Sebelum diaplikasikan untuk penanaman caisin, bokashi kotoran ternak ayam digiling terlebih dahulu agar mudah diserap oleh tanaman. Adapun cara penanamannya adalah benih caisin ditanam pada polybag dengan ukuran diameter $15 \mathrm{~cm}$, setiap polybag ditanami kurang lebih tiga butir benih caisin, setelah tanaman berumur satu minggu dipilih salah satu tanaman yang menunjukkan pertumbuhan paling baik untuk terus dipelihara, sedangkan tanaman yang lain diambil atau dicabut.

Untuk mengetahui pengaruh bokashi kotoran ternak ayam pada tanaman caisin adalah dengan menggunakan Rancangan Acak Lengkap (RAL) dengan empat macam perlakuan dan lima ulangan, masing-masing ulangan terdiri dari lima polybag. Adapun rancangan yang dilaksanakan adalah sebagai berikut :

Tabel 1. Rancangan Perlakuan dan Ulangan

\begin{tabular}{llccc}
\hline \hline Ulangan & \multicolumn{4}{c}{ Perlakuan } \\
\cline { 2 - 5 } & $\mathrm{T}_{0}$ & $\mathrm{~T}_{1}$ & $\mathrm{~T}_{2}$ & $\mathrm{~T}_{3}$ \\
\hline 1 & $\mathrm{~T}_{0} \mathrm{U}_{1}$ & $\mathrm{~T}_{1} \mathrm{U}_{1}$ & $\mathrm{~T}_{2} \mathrm{U}_{1}$ & $\mathrm{~T}_{3} \mathrm{U}_{1}$ \\
2 & $\mathrm{~T}_{0} \mathrm{U}_{2}$ & $\mathrm{~T}_{1} \mathrm{U}_{2}$ & $\mathrm{~T}_{2} \mathrm{U}_{2}$ & $\mathrm{~T}_{3} \mathrm{U}_{2}$ \\
3 & $\mathrm{~T}_{0} \mathrm{U}_{3}$ & $\mathrm{~T}_{1} \mathrm{U}_{3}$ & $\mathrm{~T}_{2} \mathrm{U}_{3}$ & $\mathrm{~T}_{3} \mathrm{U}_{3}$ \\
4 & $\mathrm{~T}_{0} \mathrm{U}_{4}$ & $\mathrm{~T}_{1} \mathrm{U}_{4}$ & $\mathrm{~T}_{2} \mathrm{U}_{4}$ & $\mathrm{~T}_{3} \mathrm{U}_{4}$ \\
5 & $\mathrm{~T}_{0} \mathrm{U}_{5}$ & $\mathrm{~T}_{1} \mathrm{U}_{5}$ & $\mathrm{~T}_{2} \mathrm{U}_{5}$ & $\mathrm{~T}_{3} \mathrm{U}_{5}$ \\
\hline
\end{tabular}

\subsubsection{Parameter Pengamatan}

Variabel yang diamati dalam penelitian aplikasi pemanfaatan bokashi kotoran ternak ayam pada tanaman caisin adalah :

\section{a. Tinggi tanaman}

Tinggi tanaman $(\mathrm{cm})$ caisin dengan cara mengukur dari pangkal batang sampai ujung tanaman tertinggi.

\section{b. Berat segar tanaman}

Berat segar (gr) di hitung dengan cara menimbang berat per tanaman setelah dipotong bagian akarnya.

\subsection{Metode analisis data}

Untuk mengetahui perbedaan dari keempat perlakuan, maka digunakan Analisis of Variance (ANOVA) satu arah (One way) yang aplikasinya menggunakan program SPSS 10.0 (Sugiono, 2001). Apabila terdapat perbedaan antara keempat perlakuan tersebut maka dilanjutkan dengan analisis Uji Wilayah Ganda Duncan (Sugandi dan Sugiarto 1996).

\section{HASIL DAN PEMBAHASAN \\ 3.1. Tinggi tanaman}

Hasil analisis statistik menunjukkan bahwa aplikasi pemanfaatan bokashi kotoran ternak ayam pada tanaman caisin berpengaruh sangat nyata $(\mathrm{P}<0,01)$ terhadap tinggi tanaman caisin, adapun hasil dari uji lanjutan duncan dapat dilihat pada Tabel 2.

Tabel 2. Rata-rata Tinggi Tanaman Caisin (cm)

\begin{tabular}{|ccccccc|}
\hline Perlakuan & \multicolumn{7}{c|}{ Ulangan } \\
\cline { 2 - 7 } & 1 & 2 & 3 & 4 & 5 & Rata-rata \\
\hline $\mathrm{T}_{0}$ & 32,3 & 34,5 & 35,4 & 34,4 & 34,8 & $34,28^{\mathrm{a}}$ \\
$\mathrm{T}_{1}$ & 37,4 & 38 & 34,2 & 34,4 & 37,6 & $36,28^{\mathrm{b}}$ \\
$\mathrm{T}_{2}$ & 33,5 & 32,2 & 32,8 & 31 & 33,4 & $32,58^{\mathrm{a}}$ \\
$\mathrm{T}_{3}$ & 28,4 & 28,6 & 31,2 & 28 & 28 & $28,84^{\mathrm{c}}$ \\
\hline
\end{tabular}

Keterangan : Tanda superskrip yang berbeda pada kolom yang sama rata-rata menunjukkan perbedaan nyata $(P<0,05)$

Hasil uji Duncan menunjukkan bahwa perlakuan $\mathrm{T}_{1}(36,28)$ berbeda nyata $(\mathrm{P}<0,05)$ dan lebih tinggi dibandingkan dengan perlakuan $\mathrm{T}_{0}(34,28), \mathrm{T}_{2}(32,58)$ dan $\mathrm{T}_{3}(28,84)$. Sementara perlakuan $\mathrm{T}_{0} \quad(34,28)$ tidak berbeda nyata $(\mathrm{P}>0,05)$ dengan perlakuan $\mathrm{T}_{2}(32,58)$ tetapi berbeda nyata dengan $T_{1}(36,28)$ dan $T_{3}(28,84)$. Tinggi tanaman caisin yang paling rendah adalah pada perlakuan $\mathrm{T}_{3}(28,84)$ berbeda nyata $(\mathrm{P}<0,05)$ dengan semua perlakuan.

Perbedaan tinggi tanaman diduga akibat kandungan $\mathrm{N}, \mathrm{P}$ da $\mathrm{K}$ yang terkandung dalam bokashi pada setiap perlakuan berbeda-beda. Adapun kandungan bokashi adalah sebagai berikut : N $1,33 \%, \mathrm{P} \quad 0,85 \%, \mathrm{~K} \quad 0,36 \%$ (Simamora dan Salundik, 2006).

Tinggi tanaman yang diperoleh dari masing-masing perlakuan berbeda, hal itu diduga karena pemberian bokashi kotoran ternak ayam yang berbeda sehingga kandungan unsur hara N, 
$\mathrm{P}$ dan K yang ada didalamnya berbeda pula. Pada perlakuan pertama yang tanpa penambahan bokashi kotoran ternak ayam hasilnya kurang bagus dibandingkan dengan perlakuan kedua dengan pemberian bokashi kotoran ternak ayam 1:0,5 dengan tanah, akan tetapi pada perlakuan ketiga dan keempat dengan dosis pemberian bokashi kotoran ternak ayam yang semakin banyak juga tidak mendapatkan hasil yang bagus.

Pupuk kandang termasuk pupuk yang lambat tersedia bagi tanaman. Pupuk kandang yang masih baru dan banyak berisi sisa-sisa pakan ternak yang masih mentah diberikan satu sampai dengan empat minggu terlebih dahulu pada tanah baru dilakukan penanaman (A A K, 2006). Berdasarkan pernyataan tersebut, maka ada kemungkinan bokashi yang ditambahkan belum terserap secara optimal oleh tanaman caisin karena jarak antara pemberian pada tanah dan jarak penanamannya sanggat singkat, hanya berselang tiga hari. Jadi pertumbuhan tanam caisin juga kurang optimal.

Gardner, dkk., (1991), menyatakan pertumbuhan vegetatif dan produksi suatu tanaman tergantung pada interaksi antara tanaman dan keadaan lingkungan dimana tanaman itu tumbuh. Salah satu usaha untuk mengatur lingkungan ini adalah dengan penambahan pupuk untuk pertumbuhan vegetatif. Penambahan N, akan memacu pertumbuhan daun dan batang namun bukan berarti pemberian zat $\mathrm{N}$ itu bisa semaunya, pemberian zat $\mathrm{N}$ berlebihan tidak baik untuk pertumbuhan (Pinus L 1997).

Tanaman yang kekurangan unsur $\mathrm{N}$ maka gejala yang timbul adalah daun pucat kekuningkuningan, mulai dari daun yang lebih tua kemudian menjalar keseluruh daun tanaman dan daun menjadi coklat kemudian lemah. Nitrogen penting untuk membangun material tanaman, merangsang tumbuhnya vegetatif yang cepat sehingga tanaman tumbuh tinggi dan memiliki warna hijau sehat. Nitrogen adalah pembentuk utama protein yang menyusun protoplasma dari satu tanaman dan bahan yang membentuk tubuh tanaman, khususnya batang dan daun tanaman. Akibat dari kekurangan unsur $\mathrm{P}$ pada tanaman adalah perkembangan akar menjadi terhambat dan batang menjadi kurus. Sedangkan unsur K akan membantu daya tahan terhadap penyakit karena dapat membentuk jaringan yang lebih kuat. Jika kekurangan unsur $\mathrm{K}$ juga dapat menimbulkan warna kuning pada daun (A A K, 2006).

\subsection{Berat segar tanaman}

Hasil analisis statistik menunjukkan bahwa aplikasi pemanfaatan bokashi kotoran ternak ayam pada tanaman caisin berpengaruh sangat nyata $(\mathrm{P}<0,01)$ terhadap berat segar tanaman caisin, adapun hasil dari uji lanjutan duncan dapat dilihat pada Tabel 3.

Tabel 3. Rata-rata Berat Segar Tanaman (gr)

\begin{tabular}{ccccccc}
\hline \hline Perlakuan & \multicolumn{6}{c}{ Ulangan } \\
\cline { 2 - 7 } & 1 & 2 & 3 & 4 & 5 & Rata-rata \\
\hline $\mathrm{T}_{0}$ & 126,4 & 127 & 127,8 & 126 & 127 & $126,84^{\mathrm{a}}$ \\
$\mathrm{T}_{1}$ & 166 & 154 & 156 & 166 & 166 & $161,60^{\mathrm{b}}$ \\
$\mathrm{T}_{2}$ & 157 & 156 & 155 & 157,4 & 159 & $156,88^{\mathrm{b}}$ \\
$\mathrm{T}_{3}$ & 131,8 & 131 & 135 & 131 & 141 & $133,96^{\mathrm{c}}$ \\
\hline
\end{tabular}

Keterangan : Superskrip yang berbeda pada kolom yang sama rata-rata menunjukan perbedaan nyata $(P<0,05)$

Hasil uji Duncan menunjukkan bahwa perlakuan $T_{1}(161,60)$ tidak berbeda nyata $(\mathrm{P}>0,05)$ dengan perlakuan $\mathrm{T}_{2}(156,88)$ akan tetapi berbeda nyata $(\mathrm{P}<0,05)$ dengan $\mathrm{T}_{0}$ $(126,84)$ dan $T_{3}(133,96)$. Sementara perlakuan $T_{3}$ $(133,96)$ berbeda nyata dengan perlakuan $\mathrm{T}_{0}$ $(126,84), \mathrm{T}_{1}(161,60)$ dan $\mathrm{T}_{2}(156,88)$. Perlakuan $\mathrm{T}_{0}(126,84)$ juga berbeda nyata $(\mathrm{P}<0,05)$ dengan semua perlakuan dan menghasilkan produksi yang paling rendah.

Peningkatan produksi tanaman caisin yang berbeda dari setiap perlakuan kemungkinan disebabkan karena perbandingan bokashi kotoran ternak ayam dari setiap perlakuan yang berbeda. Pada pemberian bokashi kotoran ternak ayam dengan dosis 1:0,5 $\left(\mathrm{T}_{1}\right)$ ternyata tidak berbeda nyata dengan pemberian bokashi kotoran ternak ayam dengan dosis 1:1 $\left(\mathrm{T}_{2}\right)$. Jadi secara ekonomis lebih menguntungkan pemberian bokashi kotoran ternak ayam dengan dosis 1:0,5 karena lebih hemat dan memberikan hasil yang baik, sedangkan secara teknis lebih menguntungkan karena dalam persiapan media tanamnya lebih afisien waktu dan tenaga. Penambahan yang tepat antara tanah dan bokashi kotoran ternak ayam ternyata mampu meningkatkan berat segar tanaman caisin. Hal ini sesuai dengan pendapat Murbandono (2006), tujuan pemupukan adalah untuk menambah hara tanaman agar dapat diserap oleh tanaman sehingga menghasilkan pertumbuhan dan produksi yang tinggi.

Tanaman yang tanpa dilakukan pemupukan terlihat jelas bahwa hasil produksi lebih rendah jika dibanding dengan ketiga perlakuan yang lain. Hal ini disebabkan karena tanaman tidak mendapatkan unsur hara $\mathrm{N}, \mathrm{P}$ dan 
K yang terdapat dalam pupuk bokashi. Suatu tanaman yang kekurangan salah satu dari unsur $\mathrm{N}, \mathrm{P}$ dan $\mathrm{K}$ menunjukkan ciri-ciri sebagai berikut: a). Kekurangan $\mathrm{N}$, maka daun tidak tampak hijau segar, melainkan agak kekuningkuningan. Jika terjadi kekurangan secara terus menerus, maka daun dibawah akan menjadi kering dan akhirnya akan gugur; b). Kekurangan $\mathrm{P}$, maka pertumbuhan akan terhambat, daun akan menjadi hijau tua. Pada lembaran bagian daun dan tangkai akan terdapat bagian yang mati dan akhirnya daun akan rontok; c). Kekurangan K, maka daun menjadi kuning, ada noda-noda jaringan mati ditengah-tengah atau bagian tepi daun, pertumbuhan terlambat, batang kurang kuat sehingga mudah patah oleh angin (A A K, 2006).

Perbedaan produksi yang terjadi kemungkinan disebabkan oleh penambahan unsur hara pada lingkungan tanaman yang diakibatkan oleh penambahan pupuk (Gardner, dkk., 1991).

Simamora dan Saludik (2006), menyatakan bahwa pemakaian bokashi sangat dianjurkan karena dapat memperbaiki produktivitas tanah, baik secara fisik, kimia, maupun biologi tanah. Secara fisik bokashi bisa menggemburkan tanah, memperbaiki aerasi dan draenase dan meningkatkan pengikatan antar partikel dan kapasitas mengikat air. Tingginya tingkat pertumbubuhan bobot basah pada $T_{1}, T_{2}$ dan $T_{3}$ kemungkinan disebabkan oleh penambahan unsur hara pada lingkungan tanaman yang diakibatkan oleh penambahan pupuk, penambahan bahan organik meningkatkan ketersediaan air karena bahan organik mengikat air. Seperti kita ketahui, bahwa kandungan airlah yang berperan utama untuk menghasilkan berat pada tanaman, akan tetapi jika terlalu banyak kandungan airnya, maka tanah menjadi becek. Keadaan tersebut tidak bagus untuk pertumbuhan tanaman khususnya caisin, karena akan menimbulkan penyakit pada bagian akar yang biasa disebut dengan pussarium $s p$., sehinnga pertumbuhan tanaman caisin akan terhambat (Pinus L, 1997).

Gardner (1991), menyatakan antara 70 sampai $90 \%$ dari bagian tanaman budidaya yang sedang aktif tumbuh terdiri dari air, yang tidak mungkin ditinggalkan untuk menyelenggarakan sebagian besar fungsi tanaman. Tanaman budidaya membutuhkan air yang konsisten untuk pertumbuhan dan perkembangan yang konsisten. Suatu tanaman budidaya yang tumbuh dengan cepat terutama terdiri dari air. Kandungan air berfariasi antara 70 dan $90 \%$, tergantung pada umur, spesies, jaringan tertentu dan lingkungan.

\section{KESIMPULAN DAN SARAN \\ 4.1. Kesimpulan}

Berdasarkan hasil penelitian diatas dapat disimpulkan bahwa; Pada perlakuan $\mathrm{T}_{1}$ dengan perbandingan antara tanah dan bokashi kotoran ternak ayam 1: 0,5 menunjukkan hasil yang paling bagus dengan tinggi $36,28 \mathrm{~cm}$ dan berat segar 161,6 gram.

\subsection{Saran}

Untuk meningkatkan produksi tanaman caisin sebaiknya dalam penanaman caisin menggunakan media tanam antara tanah dan bokashi kotoran ternak ayam dengan perbandingan 1:0,5.

\section{DAFTAR PUSTAKA}

\section{A A K. 2006. Petunjuk Peraktis Bertanam Sayuran. Aksi Agraris Kanisius. Yogyakarta}

Balitnak. 2005. Kotoran Kambing Domba pun Bisa Bernilai Ekonomis. http:// pustaka.deptan.go.id.Diakses 1 januari 2007.

Gardner, P F, Pearce R B Mitchell. 1991. Fisiologi Tanaman Budidaya. Universitas Indonesia Press. Jakarta.

Indriani, L. 2006. Membuat Kompos Secara Kilat. Penebar swadaya. Jakarta.

Murbandono, L. 2006. Membuat Kompos. Penebar swadaya. Jakarta.

Pinus, L.1997. Hidroponik Bercocok Tanam Tanpa Tanah. Penebar Swadaya. Jakarta.

Rukmana, S. 1994. Pertanian Selada Dan Andewi. Kanisius. Yogyakarta.

Setiyati. 2000. Budidaya Umbi-Umbian, Sayuran Dan Legumenosa. UT. Jakarta.

Simamora, S, dan Salundik. 2006. Meningkatkan Kualitas Kompos. Agromedia, Jakarta.

Subadiyasa, 1997. Teknologi Efektive Mikroorganisme (EM 4 ) Potensi dan Prospeknya Di Indonesia, makalah seminar Nasional Organik yang diselenggarakan di Hotel Atlit Century Park, Jakarta.

Sugandi, E. dan Sugiarto. 1996. Rancangan Percobaan. Andi Offset. Yogyakarta

Sutanto, R. 2006. Pertanian Organik. Kanisius. Yogyakarta. 